\title{
Pengembangan Lembar Kerja Geometri Transformasi Sebagai Asesmen Kemampuan Kognitif Mahasiswa berdasarkan RECCE-MODEL
}

\author{
${ }^{1}$ Emma Aidha Yasmine, ${ }^{2}$ Anis Farida Jamil, ${ }^{3}$ Arif Hidayatul Khusna \\ Universitas Muhammadiyah Malang \\ Jl. Bendungan Sutami No.188, Sumbersari, Kec. Lowokwaru, Kota Malang, Jawa Timur 65145 \\ E-mail:anisfarida@umm.ac.id
}

\section{Article History:}

Received: 31-08-2020; Received in Revised: 03-09-2020; Accepted: 22-09-2020

\begin{abstract}
The application of real-life problems to Students' Worksheet in learning transformation geometry makes learning meaningful. This is done in this study by developing Students' Worksheet using a RECCE-MODEL framework. This research uses research and development type. The 3D model used in this study contains three stages, namely the understanding stage, the manufacturing stage, and the development stage. This study uses a student response questionnaire sheet, validation sheet, and the results of students' worksheet work as research instruments. From the research results, the students' worksheet developed was declared valid with a percentage of $79 \%$, practical with a percentage of $85 \%$, and effective by grouping students' cognitive abilities based on the RECCE-MODEL. Thus, it can be concluded that the transformation geometry worksheet developed can measure the cognitive abilities of students.
\end{abstract}

Keywords: Student's Worksheet; RECCE-MODEL; Cognitive Ability; Transformation Geometry; Assessment.

\begin{abstract}
Abstrak
Penerapan LKM geometri transformasi dalam kehidupan nyata menjadikan pembelajaran matematika lebih bermakna. Hal ini dilakukan pada penelitian ini dengan mengembangkan LKM menggunakan kerangka berpikir RECCE-MODEL. Penelitian ini merupakan penelitian pengembangan dengan model 3D yaitu Define (tahap pengertian), Design (tahap pembuatan), dan Develop (tahap pengembangan). Penelitian ini menggunakan lembar angket respon mahasiswa, lembar validasi, dan hasil pengerjaan LKM sebagai instrumen penelitian. Dari hasil penelitian, LKM yang dikembangkan dinyatakan valid dengan persentase 79\%, praktis dengan persentase 85\%, dan efektif dengan pengelompokkan kemampuan kognitif mahasiswa berdasarkan RECCE-MODEL. Sehingga dapat disimpulkan bahwa lembar kerja geometri transformasi yang dikembangkan dapat mengukur kemampuan kognitif mahasiswa.
\end{abstract}

Kata Kunci: Lembar Kerja; RECCE-MODEL; Kemampuan Kognitif; Geometri Transformasi; Asesmen. 


\section{Pendahuluan}

Geometri transformasi adalah bagian dari ilmu matematika yang banyak digunakan dalam kehidupan'1. Penerapan geometri transformasi dapat dilakukan seperti menentukan kemiringan tangga dan menentukan topologi jaringan komputer ${ }^{2}$. Namun, pembelajaran geometri transformasi di kelas belum optimal karena banyak mahasiswa yang merasa kesulitan dalam memahami konsep dan memecahkan masalah ${ }^{3}$. Tak hanya itu, dalam pembelajaran juga belum menerapkan permasalahan di kehidupan nyata ${ }^{4}$. Guru biasanya hanya memberikan pengetahuan secara langsung dari buku dan gambar dengan bantuan kertas berpetak ${ }^{5}$, sehingga sulit untuk mengukur kemampuan kognitif mahasiswa.

Kemampuan kognitif adalah perolehan pengetahuan dari pengalaman belajar oleh individu atau kelompok ${ }^{6}$. Kemampuan kognitif terdiri dari enam tingkat diantaranya adalah mengingat, memahami, menerapkan, menganalisis, mengevaluasi, dan menciptakan ${ }^{7}$. Kemampuan kognitif dibutuhkan untuk menumbuhkan pengetahuan tentang apa yang dilihat, didengar, diraba, dirasa oleh semua panca indera ${ }^{8}$.

Dengan demikian, agar pembelajaran tidak hanya mencatat dan menghafal maka pembelajaran haruslah bermakna dengan memasukkan masalah di kehidupan sehari-hari ${ }^{9}$. Oleh karena itu, perlu dikembangkan

${ }^{1}$ Silfi Zainatu Sholihah and Ekasatya Aldila Afriansyah, "Analisis Kesulitan Siswa Dalam Proses Pemecahan Masalah Geometri Berdasarkan Tahapan Berpikir Van Hiele," Mosharafa6, no. 2 (2017): 287-98, https://doi.org/10.31980/mosharafa.v6i2.317.

2 Indah L. Nur'aini et al., "Pembelajaran Matematika Geometri Secara Realistis Dengan GeoGebra,” Jurnal Matematika 16, no. 2 (2017): 1-6.

3 Sholihah and Afriansyah, "Analisis Kesulitan Siswa Dalam Proses Pemecahan Masalah Geometri Berdasarkan Tahapan Berpikir Van Hiele”; Ma'rufi, Rio Fabrika Pasandaran, and Ahmad Yogi, "Pemahaman Konsep Geometri Mahasiswa Berdasarkan Gaya Kognitif Mahasiswa," Jurnal Penelitian Matematika Dan Pendidikan Matematika 1, no. 2 (2018): 5667.

${ }^{4}$ Irkham Ulil Albab, Yusuf Hartono, and Darmawijoyo, "Kemajuan Belajar Siswa Pada Geometri Transformasi Menggunakan Aktivitas Refleksi Geometri," Cakrawala Pendidikan, no. 3 (2014): 338-48; Febrian and Sukma Adi Perdana, "Memfasilitasi Penalaran Geometri Transformasi Siswa Melalui Eksplorasi Motif Melayu Dengan Bantuan GRID," Jurnal Gantang 2, no. 2 (2017): 157-64.

${ }^{5}$ Febrian and Perdana, "Memfasilitasi Penalaran Geometri Transformasi Siswa Melalui Eksplorasi Motif Melayu Dengan Bantuan GRID."

6 Aini N, "Analisis Kemampuan Kognitif Siswa Dalam Evaluasi Pembelajaran Matematika Menggunakan Model Coutenance Stake," 2016, 8-25.

${ }^{7}$ Friska Octavia Rosa, "Eksplorasi Kemampuan Kognitif Siswa Terhadap Kemampuan Memprediksi, Mengobservasi, Dan Menjelaskan Ditinjau Dari Gender," Jurnal Pendidikan Fisika Universitas Muhammadiyah Metro 5, no. 2 (2017): 111-18.

8 Sri Natacik, "Peningkatan Kemampuan Kognitif Melalui Kegiatan Menggambar Bentuk-Bentuk Geometri Bagi AUD," Jurnal Ilmiah Tumbuh Kembang Anak Usia Ini 3, no. 3 (2018): 205-18.

9 Rahmita Yuliana Gazali, "Pembelajaran Matematika Yang Bermakna," Math Didactic: Jurnal Pendidikan Matematika 2, no. 3 (2016): 181-90, https://doi.org/10.33654/math.v2i3.47. 
bahan ajar untuk membantu dan meningkatkan proses pembelajaran dalam bentuk Lembar Kerja Mahasiswa (LKM) ${ }^{10}$. LKM merupakan lembaran yang berisi resume materi, contoh soal dan latihan soal ${ }^{11}$. LKM dapat membantu dalam pemahaman materi dan menuntut mahasiswa untuk memecahkan masalah ${ }^{12}$. Pengembangan LKM dalam menciptakan pembelajaran geometri transformasi yang bermakna yaitu berdasarkan kerangka berpikir RECCEMODEL.

Kerangka berpikir RECCE-MODEL lebih mengutamakan pemahaman matematika dalam kehidupan sehari-hari ${ }^{13}$. Maksud RECCE adalah Realistic (Realistic), Education (Pendidikan), Contextual (Kontekstual), Cognitive (Kognitif), dan Evaluation (Penilaian) sedangkan maksud MODEL adalah Meanings (Bermakna), Organise (Mengorganisasi), Develop (Membangun), Execute (Melaksanakan), dan Link(Menghubungkan). Kerangka kerja RECCEMODEL merupakan suatu kerangka kerja yang menggabungkan pemecahan masalah dalam kehidupan nyata dengan pembelajaran di kelas dan kerangka MODEL digunakan untuk menilai tingkat kompetensi mahasiswa dalam menyelesaikan soal yang berhubungan dengan masalah di kehidupan nyata ${ }^{14}$. Pada kerangka MODEL, memuat beberapa level yang digunakan untuk mengukur kemampuan kognitif mahasiswa yaitu Level 1-Meanings, Level 2Organise, Level 3-Develop, Level 4-Execute, dan Level 5-Link ${ }^{15}$.

Pada penelitian terdahulu terkait pengembangan LKM memperoleh tanggapan baik dari mahasiswa dan dapat meningkatkan nilai belajar, motivasi belajar, keaktifan mahasiswa, serta menciptakan pembelajaran yang efektif, dan membantu pemahaman konsep ${ }^{16}$. Penelitian tentang penggunaan

10 Rio Fabrika Pasandaran, Desak Made Ristia Kartika, and Eva Dwika Masni, “Pengembangan Lembar Kerja Mahasiswa (LKM) Pada Pembuktian Dalil-Dalil Segitiga," in Prosiding Seminar Nasional, vol. 03, 2018, 147-53; Kenys Fadhilah Zamzam, Siti Napfiah, and Asri Putri Anugraini, "Persepsi Mahasiswa Terhadap LKM Geometri Transformasi Berbasis Discovery Learning Dengan Pendekatan Kontekstual," Jurnal Matematika Dan Pembelajaran 6, no. 1 (2018): 65-69.

11 Mona Adria Wirda et al., "Pengembangan Lembar Kerja Mahasiswa (LKM) Berbasis Project Pada Mata Kuliah Evaluasi Hasil Belajar Geografi TA 2017/2018," Jurnal Geografi 10, no. 2 (2018): 164-75.

12 Aan Subhan Pamungkas and Yuyu Yuhana, "Pengembangan Bahan Ajar Untuk Peningkatan Kemampuan Penalaran Matematis Mahasiswa Calon Guru Matematika," JPPM9, no. 2 (2016): 177-82; Meina Febriani, "Pemanfaatan Lembar Kerja Mahasiswa Untuk Meningkatkan Keaktifan Mahasiswa: Studi Penerapan Lesson Study Pada Mata Kuliah Buku Teks Pelajaran Bahasa Indonesia," Jurnal Pendidikan Bahasa Dan Sastra 16, no. 1 (2016): 20312.

13 Maureen Siew Fang Chong, Masitah Shahrill, and Hui Chuan Li, "The Integration of a Problem Solving Framework for Brunei High School Mathematics Curriculum in Increasing Student's Affective Competency," Journal on Mathematics Education 10, no. 2 (2019): 215-28.

14 Ibid.

15 Ibid.

16 Susanah, "Pengembangan Lembar Kegiatan Mahasiswa Matematika Dasar," Buana Matematika: Jurnal Ilmiah Matematika Dan Pendidikan Matematika 9, no. 1 (2019): 7-12, https://doi.org/10.36456/buana_matematika.9.1:.1977.7-12; Wirda et al., "Pengembangan 
kerangka kerja RECCE- MODEL dalam pembelajaran mampu memberikan pengalaman belajar matematika secara realistis melalui pemecahan masalah dalam kehidupan nyata di kelas, pembelajaran lebih aktif, dan mampu mendorong pengembangan kompetensi kognitif 17. Dengan demikian, pengembangan LKM menggunakan kerangka kerja RECCE-MODEL mampu menciptakan pembelajaran yang bermakna dan dapat digunakan untuk mengukur kemampuan kognitif mahasiswa. Tujuan penelitian adalah mengembangkan lembar kerja geometri transformasi menggunakan kerangka kerja RECCE-MODEL sebagai alat untuk mengukur kemampuan kognitif mahasiswa yang praktis, valid, dan efektif.

\section{Metode}

Jenis penelitian dengan mengembangkan LKM ini menggunakan jenis penelitian research and development. Pengembangan LKM ini dibuat untuk mahasiswa semester 7 dengan menyesuaikan model 4D yang kemudian dirubah menjadi 3D, yakni pengertian/define, pembuatan/design, dan pengembangan/develop. Tahap diseminasi tidak dilakukan pada penelitian ini karena terbatasnya waktu penelitian.

Pada tahap define, akan dilakukan kegiatan yang meliputi : (1) studi asal, untuk mencari informasi yang melandasi pengembangan LKM; (2) studi mahasiswa, untuk memahami karakter mahasiswa sebagai acuan LKM yang dikembangkan seperti jumlah mahasiswa, jenis kelamin, dan yang lain; (3) studi konsep, dengan menyusun ranangan materi yang dipelajari, yaitu translasi; (4) studi tugas, menentukan tugas yang harus dikuasai dengan memuat masalah kehidupan nyata agar dapat mencapai kompetensi yang harus dicapai.

Pada tahap design, kegiatan yang akan dilakukan yaitu menyusun LKM. Penyusunan ini dilakukan dengan merancang tugas pada LKM yang sesuai dengan studi tugas dan format. Format LKM yang dirancang meliputi: (a) halaman depan atau cover; (b) identitas mahasiswa; (c) petunjuk penggunaan; (d) masalah matematika.

Pada tahap develop dilakukan pengujian LKM yang telah dikembangkan kepada dosen ahli yang disebut validasi. Proses validasi dilakukan dengan tujuan menentukan kevalidan LKM yang telah dibuat. Setelah dinyatakan valid

Lembar Kerja Mahasiswa (LKM) Berbasis Project Pada Mata Kuliah Evaluasi Hasil Belajar Geografi TA 2017/2018”; Tri Dyah Prastiti et al., "Pengembangan Lembar Kerja Mahasiswa Berbasisis REACT (Relating, Experiencing, Applying, Coorperating, Transfering) Pada Tutorial Statistika Pendidikan Di Universitas Terbuka," AdMathEdu 7, no. 1 (2017): 61-72; Febriani, "Pemanfaatan Lembar Kerja Mahasiswa Untuk Meningkatkan Keaktifan Mahasiswa: Studi Penerapan Lesson Study Pada Mata Kuliah Buku Teks Pelajaran Bahasa Indonesia."

${ }^{17}$ Chong, Shahrill, and Li, "The Integration of a Problem Solving Framework for Brunei High School Mathematics Curriculum in Increasing Student's Affective Competency." 
ataupun sudah melakukan perbaikan atau revisi, LKM diujicobakan kepada mahasiswa.

Instrumen pada penelitian ini yakni lembar validasi, angket respon mahasiswa, dan hasil pengerjaan LKM. Angket respon mahasiswa diberikan untuk mengetahui LKM yang dikembangkan praktis atau tidak. Sementara itu, hasil pengerjaan LKM akan dianalisis untuk mengukur kemampuan kognitif mahasiswa. Standar keefektifan LKM ini ditinjau dari aspek hasil pengerjaan LKM, standar kevalidan ditinjau dari validasi validator dan standar kepraktisan dari angket respon mahasiswa setelah LKM diujicoba. Kemudian, dilakukan studi data dengan menggunakan skala likert. Berikut penskoran pada lembar validasi dan angket respon mahasiswa.

Tabel 1. Penskoran Validasi dan Angket Respon Mahasiswa

\begin{tabular}{ccc}
\hline No & Pilihan Jawaban & Skor \\
\hline 1. & Sangat Setuju (SS) & 4 \\
2. & Setuju (S) & 3 \\
3. & Tidak Setuju (TS) & 2 \\
4. & Sangat Tidak Setuju (STS) & 1 \\
\hline
\end{tabular}

Berdasarkan penskoran pada Tabel 1, rumus persentase yang digunakan adalah sebagai berikut:

$$
P=\frac{\sum x}{\sum x_{i}} \times 100 \%
$$

Keterangan:

$P \quad=$ persentase validitas per aspek

$\sum x=$ jumlah jawaban responden per aspek

$\sum x_{i}=$ jumlah nilai ideal per aspek

Tabel 2. Kategori Persentase Hasil Validasi

\begin{tabular}{ccc}
\hline No. & Tingkat Pencapaian $(\boldsymbol{P})$ dalam \% & Kategori \\
\hline 1. & $75<P \leq 100$ & Sangat Valid \\
2. & $50<P \leq 75$ & Valid \\
3. & $25<P \leq 50$ & Kurang Valid \\
4. & $0 \leq P \leq 25$ & Tidak Valid \\
\hline
\end{tabular}

Berdasarkan hasil validasi, LKM dapat diujicobakan ketika memenuhi kriteria minimal valid.

Tabel 3. Kategori Persentase Hasil Respon Mahasiswa

\begin{tabular}{ccc}
\hline No. & Tingkat Pencapaian $(\boldsymbol{P})$ dalam\% & Kategori \\
\hline 1. & $50<P \leq 100$ & Positif \\
2. & $0 \leq P \leq 50$ & Negatif \\
\hline
\end{tabular}



Oktober-2020, Vol.8, No.2, hal.145-158

LKM dikatakan praktis ketika hasil angket respon mahasiswa berkategori positif. Analisis hasil pengerjaan LKM dilakukan dengan menggunakan kerangka RECCE-MODEL yang terdiri dari 5 (lima) level. Level 1-Meanings menyatakan bahwa mahasiswa dapat memahami tentang masalah yang diberikan, Level 2-Organise menyatakan bahwa mahasiswa dapat menentukan strategi dalam memecahkan masalah, Level 3-Develop menyatakan bahwa mahasiswa dapat menentukan rumus matematika yang dapat digunakan dalam pemecahan masalah, Level 4-Execute menyatakan bahwa mahasiswa dapat menerapkan strategi untuk mendapatkan solusi matematika, Level 5-Link menyatakan bahwa mahasiswa dapat menghubungkan solusi matematika pada permasalahan dan merefleksi kesalahan ${ }^{18}$.

\section{Hasil dan Diskusi}

Penelitian yang mengembangkan LKM berdasarkan kerangka berpikir RECCE-MODEL menggunakan model 4D yang dirubah menjadi 3D. Penelitian dilakukan sesuai dengan tahapan yang sesuai dengan model 3D, yaitu pengertian/define, pembuatan/design, dan pengembangan/develop ${ }^{19}$.

1. Tahap Pendefinisian/Define

Pada tahap ini dilakukan studi asal dengan mengidentifikasi masalah dalam pembelajaran mata kuliah geometri transformasi dalam materi translasi. Pada penelitian 20 dan 21 yang menjelaskan bahwa dalam pembelajaran geometri transformasi kurang memanfaatkan permasalahan di kehidupan nyata. Selanjutnya studi mahasiswa, dilakukan pengenalan karakteristik mahasiswa. Beberapa penelitian terdahulu terkait penggunaan LKM ternyata dapat memberikan hasil belajar lebih tinggi serta dapat mempermudah proses pembelajaran ${ }^{22}$ maka peneliti menggunakan LKM sebagai bahan ajar. Dalam penelitian ini, subjeknya adalah mahasiswa

18 Ibid.

${ }^{19}$ Hawwin Fitra Raharja, "Pengembangan Multimedia Flash Pada Materi Bentuk-Bentuk Hubungan Sosial," Ed-Humanistics 3, no. 1 (2018): 262-69; Atik Nur Wahyuningsih and Kustiarini, "Pengembangan Perangkat Pembelajaran Menggambar Berbasis Outdoor Learning Bagi Siswa Sekolah Dasar," Jurnal Riset Pendidikan Dasar01, no. 2 (2018): 84-100; Sri Widadi, Mega Teguh Budiarto, and Tatag Yuli Eko Siswono, "Pengembangan Perangkat Pembelajaran Dengan Pemecahan Masalah Untuk Melatih Kemampuan Berpikir Kreatif Siswa Kelas IV SD Materi Pecahan," Jurnal Review Pendidikan Dasar 2, no. 2 (2016): 152-58.

20 Sri Hartati and Yusuf Hartono, "Belajar Pencerminan Dengan Menggunakan Permainan Bom-Boman Di Kelas VII," Jurnal Review Pembelajaran Matematika 3, no. 1 (2018): 49-61.

21 Oktavianus Mamoh, "Pengembangan Perangkat Lembar Kerja Siswa Dengan Menggunakan Pendekatan Matematika Realistik Pada Materi Transformasi Siswa Kelas VII SMP," Jurnal Sigma 2, no. 2 (2017): 59-66.

22 Marisa Indriani, Choirun Niswah, and Sujinal Arifin, "Pengembangan Lembar Kerja Peserta Didik (LKPD) Berbasis Inkuiri Terbimbing Pada Materi Transformasi Geometri," n.d., 165-80. 
semester 7 dengan jumlah 22 mahasiswa perempuan dan 6 mahasiswa lakilaki. Mahasiwa tersebut berasal dari berbagai daerah diantaranya yaitu Jawa Timur, Kalimantan, NTB, NTT, dan lainnya. Kemampuan yang dimiliki mahasiswa tersebut juga dapat dikatakan menengah.

Selanjutnya dilanjutkan studi konsep dan studi tugas. Hal yang dilakukan pada studi konsep adalah menghimpun dan menentukan konsep/materi yang sesuai ${ }^{23}$, yaitu translasi. Konsep/materi yang telah terkumpul kemudian disusun secara runtut ${ }^{24}$. Materi yang disusun adalah materi translasi yang dikaitkan dengan permasalahan di kehidupan nyata seperti pergeseran yang terjadi dalam permainan catur, serta diberikan penjelasan tentang pembuktian teorema. Studi ini dilakukan agar mahasiswa lebih memahami konsep translasi dan dapat menerapkannya dalam kehidupan ${ }^{25}$. Studi tugas dilakukan dengan menyusun beberapa permasalahan dalam kehidupan nyata. Dengan demikian, LKM yang dikembangkan dapat meningkatkan keterampilan dalam pemecahan masalah dalam kehidupan sehari-hari. Hasil studi tugas pada LKM disajikan dalam Gambar 1.

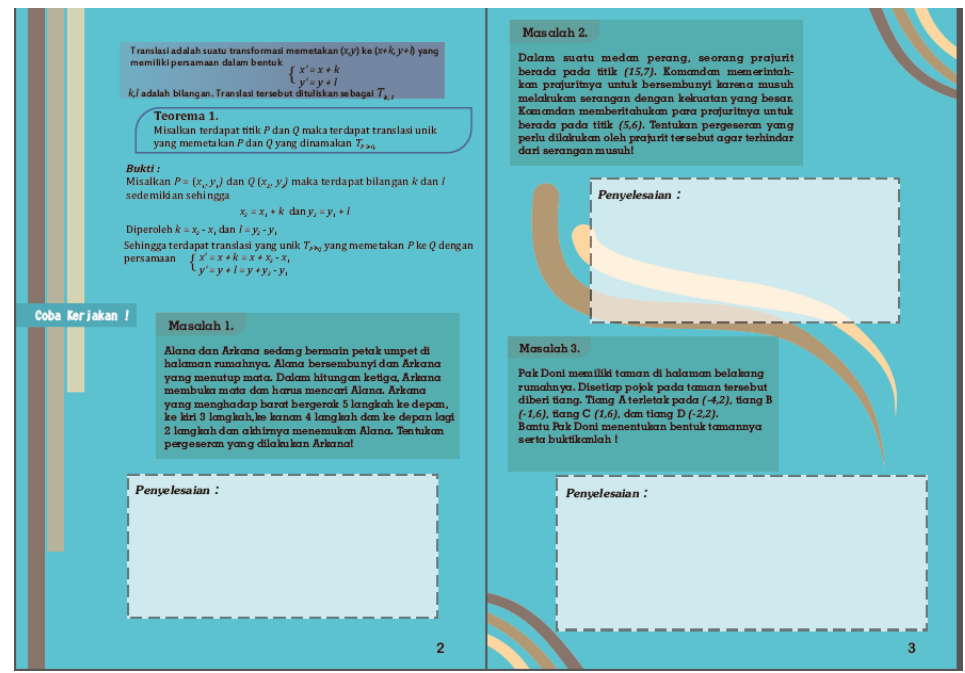

Gambar 1. Studi Tugas

23 Wahyuningsih and Kustiarini, "Pengembangan Perangkat Pembelajaran Menggambar Berbasis Outdoor Learning Bagi Siswa Sekolah Dasar"; Muchamad Subali Noto, "Perangkat Pembelajaran Matematika Berbasis Smart (Specific, Measurable, Achievable, Realistic, and Time-Bound)," Jurnal Ininity 3, no. 1 (2014): 18-32.

24 Mamoh, "Pengembangan Perangkat Lembar Kerja Siswa Dengan Menggunakan Pendekatan Matematika Realistik Pada Materi Transformasi Siswa Kelas VII SMP."

${ }^{25}$ Lia Prastyawati and Farida Hanum, "Pengembangan Model Pembelajaran Pendidikan Multikultual Berbasis Proyek Di SMA," Harmoni Sosial: Jurnal Pendidikan IPS 2, no. 1 (2015): 21-29. 


\section{Tahap Pembuatan/Design}

Pada tahap ini LKM didibuat semenarik mungkin dengan menggunakan bahasa yang jelas sehingga dapat membantu proses pembelajaran ${ }^{26}$ dengan tetap memperhatikan hasil dari studi pada tahap define. LKM dibuat dengan format: (a) halaman depan atau cover, (b) identitas mahasiswa; (c) petunjuk penggunaan; dan (d) masalah matematika.

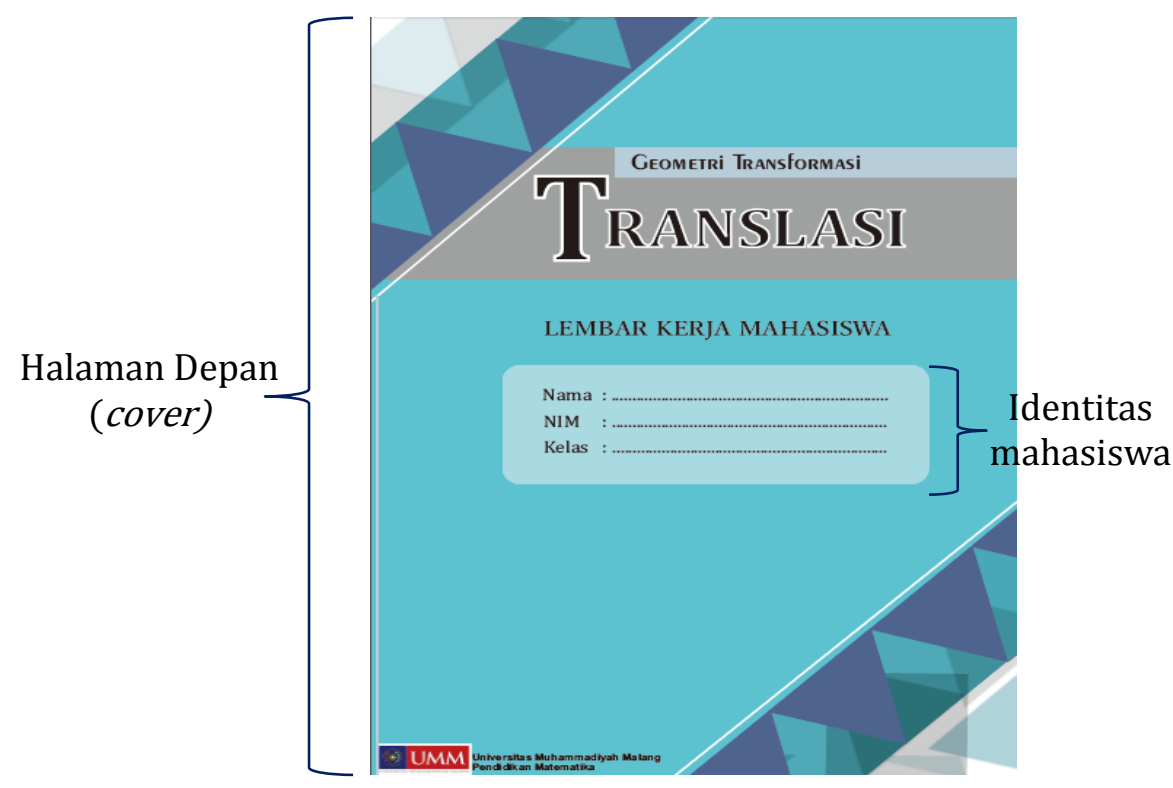

Gambar 2. Halaman Depan LKM

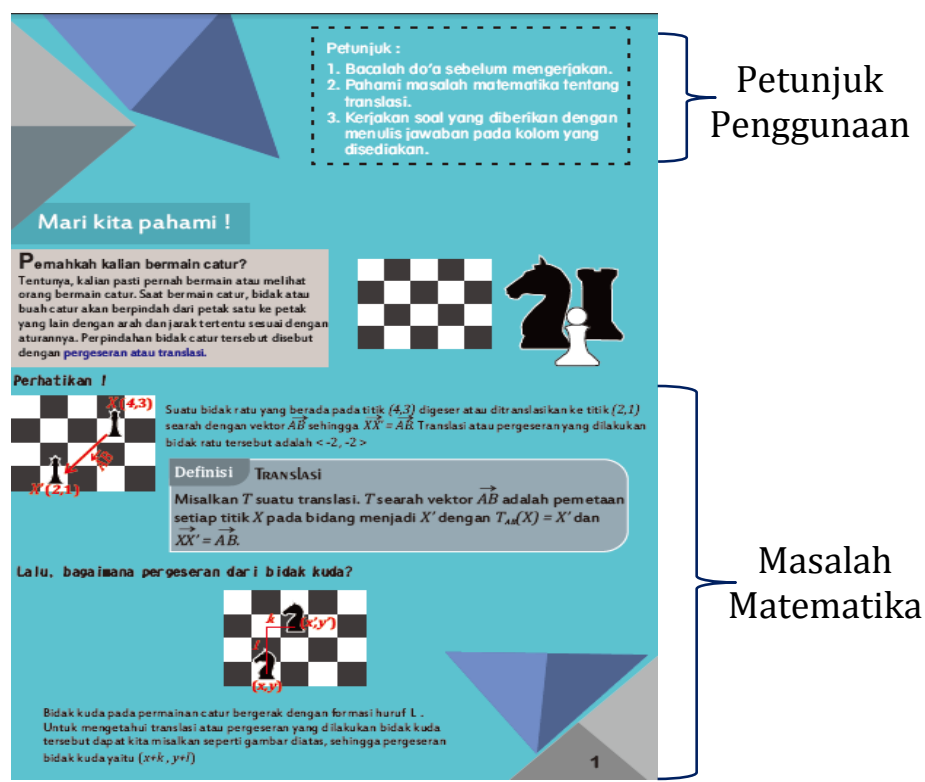

Gambar 3. Masalah Matematika

${ }^{26}$ Ade Yulia Ningsih, Syahrul R, and Ena Noveria, "Pengembangan Lembar Kerja Siswa (LKS) Materi Teks Eksposisi Dengan Teknik Copy The Master Siswa Kelas X SMK Kartika 1-2 Padang," Jurnal Pendidikan Bahasa Dan Sastra Indonesia 7, no. 3 (2018): 1-8. 
3. Tahap Pengembangan/Develop

Tahap ini memuat dua langkah yakni validasi dan uji coba dengan mahasiswa ${ }^{27}$. Setelah LKM telah dibuat sesuai dengan model 3D, dilakukan validasi oleh dua orang validator, yaitu Octavina Rizky Utami Putri,M.Pd dan Zukhrufurrohmah,M.Pd selaku dosen pendidikan matematika. Kegiatan validasi dilakukan oleh validator untuk menguji kelayakan dari LKM yang dikembangkan dan menjadi pedoman menyempurnakan LKM ${ }^{28}$. Kemudian, validator memberikan penilaian terhadap LKM yang dikembangkan meliputi aspek kelayakan isi, kelayakan bahasa, kesesuaian terhadap kerangka kerja RECCE-MODEL, dan kelayakan kegrafikan. Setelah validator melakukan penilaian, LKM dapat dinyatakan valid atau tidak berdasarkan hasil validasi. Berikut hasil uji kevalidan.

Tabel 4. Studi Uji Kevalidan

\begin{tabular}{cccccc}
\hline No & Aspek Penilaian & V1 (\%) & V2 (\%) & Rata-Rata & Kategori \\
\hline 1. & Kepantasan Isi & 85 & 75 & $80 \%$ & Sangat Valid \\
2. & Kepantasan Bahasa & 70 & 80 & $75 \%$ & Valid \\
3. & RECCE-MODEL & 87,5 & 87,5 & $87,5 \%$ & Sangat Valid \\
4. & Kepantasan Kegrafikan & 75 & 75 & $75 \%$ & Valid \\
& Rata - rata & & & $\mathbf{7 9 \%}$ & Sangat Valid \\
\hline
\end{tabular}

Berdasarkan Tabel 4, LKM dikatakan sangat valid sehingga layak diujicobakan kepada mahasiswa. LKM diperbaiki sesuai dengan catatan yang diberikan validator. Beberapa catatan validator dapat dilihat pada Tabel 5.

27 Dian Kurniawan and Sinta Verawati Dewi, "Pengembangan Perangkat Pembelajaran Dengan Media Screencast O-Matic Mata Kuliah Kalkulus 2 Menggunakan Model 4-D Thiagarajan," Jurnal Siliwangi 3, no. 1 (2017): 214-19; Widadi, Budiarto, and Siswono, "Pengembangan Perangkat Pembelajaran Dengan Pemecahan Masalah Untuk Melatih Kemampuan Berpikir Kreatif Siswa Kelas IV SD Materi Pecahan"; Prastyawati and Hanum, "Pengembangan Model Pembelajaran Pendidikan Multikultual Berbasis Proyek Di SMA"; Noto, "Perangkat Pembelajaran Matematika Berbasis Smart (Specific, Measurable, Achievable, Realistic, and Time-Bound)."

${ }^{28}$ Muhammad Irfan and Syahrani, "Pengembangan Lembar Kerja Siswa Berbasis Metode Mind Map Pada Mata Pelajaran IPA Di Sekolah Dasar," JIKAP PGSD 1, no. 2 (2017): 107-14; Panji Hidayat, "Pengembangan Instrumen Baku Penilaian Kualitas Lembar Kerja Siswa Tematik Subsains Sekolah Dasar Kelas Tinggi," Al-Bidayah: Jurnal Pendidikan Dasar Islam 7, no. 2 (2015): 170-80. 
Tabel 5. Catatan Validasi

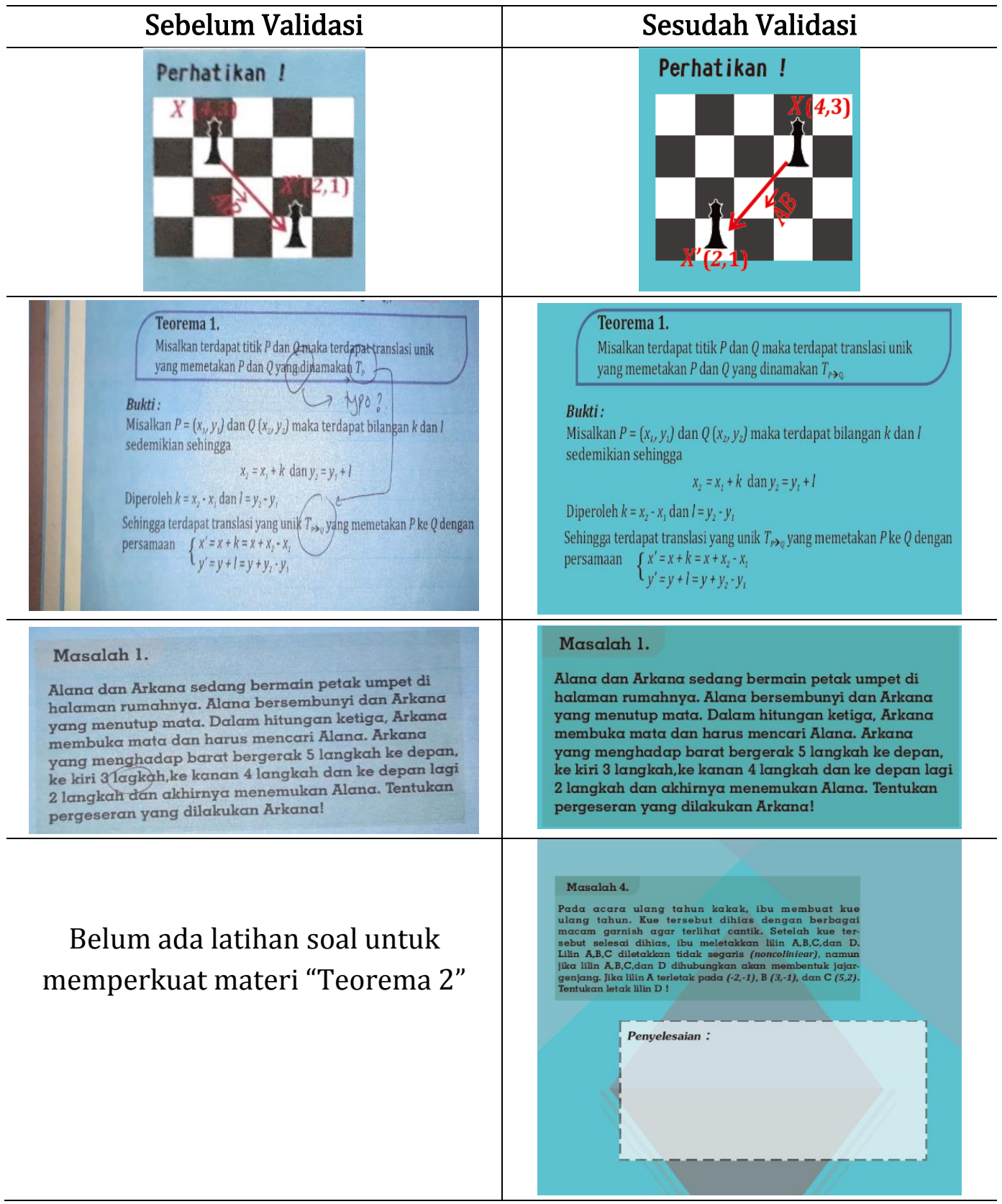

LKM yang telah diperbaiki kemudian diberikan kepada mahasiswa untuk dilakukan ujicoba. Setelah mahasiswa memahami dan menyelesaikan LKM tersebut, dilakukan uji kepraktisan dengan penyebaran angket respon mahasiswa. Angket yang telah diisi dikumpulkan untuk mengetahui apakah LKM dapat dikatakan praktis atau tidak. Hasil uji kepraktisan dapat dilihat pada Tabel 6. 

Oktober-2020, Vol.8, No.2, hal.145-158

Tabel 6. Studi Uji Kepraktisan

\begin{tabular}{cccc}
\hline No & Aspek Penilaian & $\begin{array}{c}\text { Persentase } \\
\text { Kevalidan }\end{array}$ & Kategori \\
\hline 1. & Ketertarikan & $82 \%$ & Positif \\
2. & Materi & $83 \%$ & Positif \\
3. & Bahasa & $91 \%$ & Positif \\
& Rata - rata & $\mathbf{8 5} \%$ & Positif \\
\hline
\end{tabular}

Berdasarkan hasil respon angket mahasiswa pada Tabel 5, dapat dikatakan bahwa LKM termasuk praktis dengan persentase rata-rata 85\%. Dengan demikian, LKM tersebut dapat diterapkan dalam proses pembelajaran.

Selanjutnya, semua hasil pengerjaan soal-soal yang ada dalam LKM dianalisis sesuai dengan level pada kerangka RECCE-MODEL dan pedoman jawaban yang telah menggunakan level RECCE-MODEL

Tabel 7. Level RECCE-MODEL29

\begin{tabular}{cl}
\hline Level & \multicolumn{1}{c}{ Kompetensi Kognitif } \\
\hline L1-Meanings & Mencoba membuat asumsi \\
& Memahami masalah yang diberikan \\
L2-Organise & Menentukan strategi dalam pemecahan masalah \\
L3-Develop & Menentukan rumus matematika yang dapat digunakan \\
L4-Execute & Menerapkan strategi untuk mendapatkan solusi \\
& matematika \\
L5-Link & Menghubungkan solusi matematika pada permasalahan \\
& Merefleksi kesalahan \\
\hline
\end{tabular}
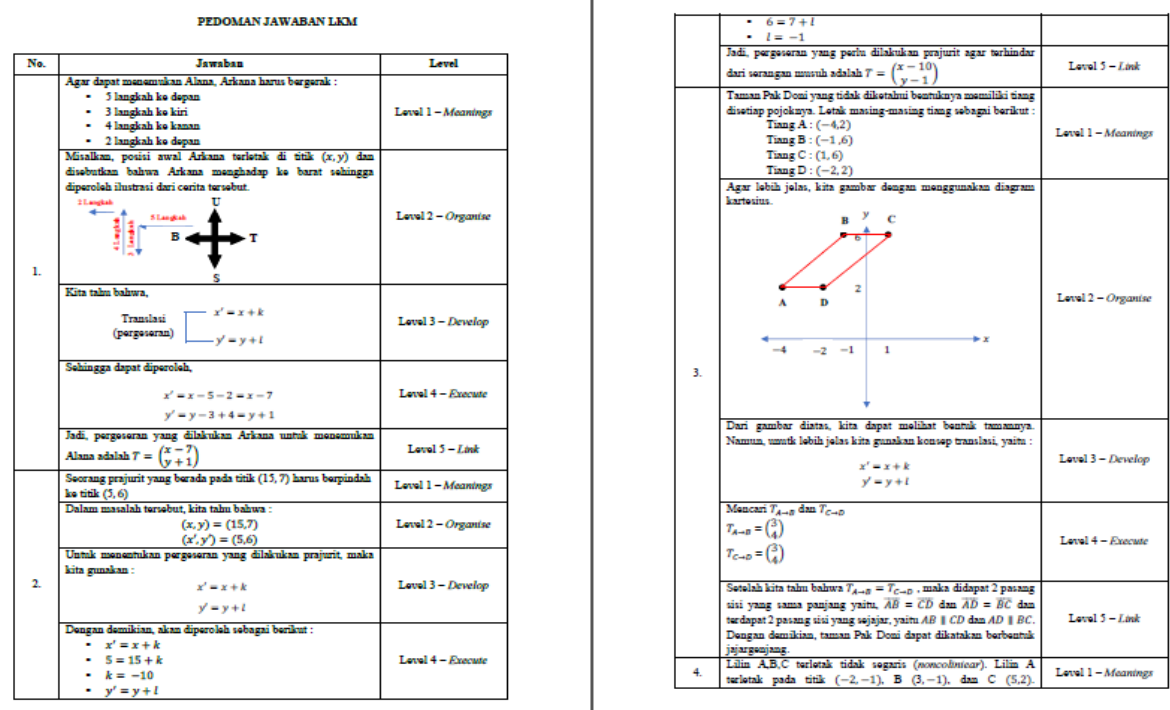

Gambar 4. Pedoman Jawaban LKM

${ }^{29}$ Chong, Shahrill, and Li, "The Integration of a Problem Solving Framework for Brunei High School Mathematics Curriculum in Increasing Student's Affective Competency." 
Setelah semua hasil pengerjaan LKM dianalisis, mahasiswa kemudian dikelompokkan ke dalam kategori level 1 sampai dengan 5. Pengelompokkan tersebut dapat digunakan untuk mengukur kemampuan kognitif mahasiswa berdasarkan RECCE-MODEL. Hasil pengelompokkan analisis hasil pengerjaan LKM seperti terlihat pada Tabel 8.

Tabel 8. Pengelompokkan Hasil Pengerjaan LKM

\begin{tabular}{ccc}
\hline No & Level & Jumlah Mahasiswa \\
\hline 1. & Lv. 1 & - \\
2. & Lv. 2 & - \\
3. & Lv. 3 & 1 \\
4. & Lv. 4 & 10 \\
5. & Lv. 5 & 17 \\
& Total & 28 \\
\hline
\end{tabular}

Berdasarkan analisis hasil pengerjaan LKM pada tabel Tabel 8, terdapat 1 mahasiswa termasuk dalam level 3-Develop, 10 mahasiswa termasuk dalam level 4-Execute, dan 17 mahasiswa termasuk dalam level 5-Link. Dengan demikian, pengembangan LKM ini dapat mengukur kemampuan kognitif mahasiswa sehingga dapat dikatakan efektif.

\section{Kesimpulan}

Penelitian ini menggunakan jenis penelitian research and development melalui tiga tahap, yaitu tahap pengertian adalah tahap yang dilakukan dengan mengumpulkan informasi untuk pengembangan LKM, tahap pembuatan adalah tahap melakukan penyusunan LKM, dan tahap pengembangan adalah tahap pengujian LKM yang dikembangkan. LKM yang dikembangkan dinyatakan valid berdasarkan uji kevalidan dengan persentase 79\%, dinyatakan praktis berdasarkan uji kepraktisan dengan persentase 85\%, dan dinyatakan efektif karena dapat mengukur kemampuan kognitif mahasiswa berdasakan level-level pada kerangka RECCE-MODEL dengan hasil analisis terdapat 1 mahasiswa tergolong level 3-Develop, 10 mahasiswa tergolong level 4-Execute, dan 17 mahasiswa tergolong level 5-Link.

\section{Daftar Pustaka}

Albab, Irkham Ulil, Yusuf Hartono, and Darmawijoyo. "Kemajuan Belajar Siswa Pada Geometri Transformasi Menggunakan Aktivitas Refleksi Geometri." Cakrawala Pendidikan, no. 3 (2014): 338-48.

Chong, Maureen Siew Fang, Masitah Shahrill, and Hui Chuan Li. "The Integration of a Problem Solving Framework for Brunei High School Mathematics Curriculum in Increasing Student's Affective Competency." Journal on Mathematics Education 10, no. 2 (2019): 215-28. 
Febrian, and Sukma Adi Perdana. "Memfasilitasi Penalaran Geometri Transformasi Siswa Melalui Eksplorasi Motif Melayu Dengan Bantuan GRID." Jurnal Gantang 2, no. 2 (2017): 157-64.

Febriani, Meina. "Pemanfaatan Lembar Kerja Mahasiswa Untuk Meningkatkan Keaktifan Mahasiswa: Studi Penerapan Lesson Study Pada Mata Kuliah Buku Teks Pelajaran Bahasa Indonesia." Jurnal Pendidikan Bahasa Dan Sastra 16, no. 1 (2016): 203-12.

Gazali, Rahmita Yuliana. "Pembelajaran Matematika Yang Bermakna." Math Didactic: Jurnal Pendidikan Matematika 2, no. 3 (2016): 181-90. https://doi.org/10.33654/math.v2i3.47.

Hartati, Sri, and Yusuf Hartono. "Belajar Pencerminan Dengan Menggunakan Permainan Bom-Boman Di Kelas VII." Jurnal Review Pembelajaran Matematika 3, no. 1 (2018): 49-61.

Hidayat, Panji. "Pengembangan Instrumen Baku Penilaian Kualitas Lembar Kerja Siswa Tematik Subsains Sekolah Dasar Kelas Tinggi." Al-Bidayah: Jurnal Pendidikan Dasar Islam 7, no. 2 (2015): 170-80.

Indriani, Marisa, Choirun Niswah, and Sujinal Arifin. "Pengembangan Lembar Kerja Peserta Didik (LKPD) Berbasis Inkuiri Terbimbing Pada Materi Transformasi Geometri," n.d., 165-80.

Irfan, Muhammad, and Syahrani. "Pengembangan Lembar Kerja Siswa Berbasis Metode Mind Map Pada Mata Pelajaran IPA Di Sekolah Dasar.” JIKAP PGSD 1, no. 2 (2017): 107-14.

Kurniawan, Dian, and Sinta Verawati Dewi. "Pengembangan Perangkat Pembelajaran Dengan Media Screencast O-Matic Mata Kuliah Kalkulus 2 Menggunakan Model 4-D Thiagarajan." Jurnal Siliwangi 3, no. 1 (2017): 214-19.

Mamoh, Oktavianus. "Pengembangan Perangkat Lembar Kerja Siswa Dengan Menggunakan Pendekatan Matematika Realistik Pada Materi Transformasi Siswa Kelas VII SMP." Jurnal Sigma 2, no. 2 (2017): 59-66.

Ma'rufi, Rio Fabrika Pasandaran, and Ahmad Yogi. "Pemahaman Konsep Geometri Mahasiswa Berdasarkan Gaya Kognitif Mahasiswa." Jurnal Penelitian Matematika Dan Pendidikan Matematika 1, no. 2 (2018): 5667.

N, Aini. "Analisis Kemampuan Kognitif Siswa Dalam Evaluasi Pembelajaran Matematika Menggunakan Model Coutenance Stake," 8-25, 2016.

Natacik, Sri. "Peningkatan Kemampuan Kognitif Melalui Kegiatan Menggambar Bentuk-Bentuk Geometri Bagi AUD." Jurnal Ilmiah Tumbuh Kembang Anak Usia Ini 3, no. 3 (2018): 205-18.

Ningsih, Ade Yulia, Syahrul R, and Ena Noveria. "Pengembangan Lembar Kerja Siswa (LKS) Materi Teks Eksposisi Dengan Teknik Copy The Master Siswa Kelas X SMK Kartika 1-2 Padang." Jurnal Pendidikan Bahasa Dan Sastra Indonesia 7, no. 3 (2018): 1-8.

Noto, Muchamad Subali. "Perangkat Pembelajaran Matematika Berbasis Smart (Specific, Measurable, Achievable, Realistic, and Time-Bound)." Jurnal Ininity 3, no. 1 (2014): 18-32. 
Nur'aini, Indah L., Erwin Harahap, Farid H. Badruzzaman, and Deni Darmawan. "Pembelajaran Matematika Geometri Secara Realistis Dengan GeoGebra." Jurnal Matematika 16, no. 2 (2017): 1-6.

Pamungkas, Aan Subhan, and Yuyu Yuhana. "Pengembangan Bahan Ajar Untuk Peningkatan Kemampuan Penalaran Matematis Mahasiswa Calon Guru Matematika." JPPM9, no. 2 (2016): 177-82.

Pasandaran, Rio Fabrika, Desak Made Ristia Kartika, and Eva Dwika Masni. "Pengembangan Lembar Kerja Mahasiswa (LKM) Pada Pembuktian Dalil-Dalil Segitiga." In Prosiding Seminar Nasional, 03:147-53, 2018.

Prastiti, Tri Dyah, Jackson Pasini Mairing, Estu Puji Handayani, and Statistika Pendidikan. "Pengembangan Lembar Kerja Mahasiswa Berbasisis REACT (Relating, Experiencing, Applying, Coorperating, Transfering) Pada Tutorial Statistika Pendidikan Di Universitas Terbuka." AdMathEdu 7, no. 1 (2017): 61-72.

Prastyawati, Lia, and Farida Hanum. "Pengembangan Model Pembelajaran Pendidikan Multikultual Berbasis Proyek Di SMA." Harmoni Sosial: Jurnal Pendidikan IPS 2, no. 1 (2015): 21-29.

Raharja, Hawwin Fitra. "Pengembangan Multimedia Flash Pada Materi Bentuk-Bentuk Hubungan Sosial." Ed-Humanistics 3, no. 1 (2018): 26269.

Rosa, Friska Octavia. "Eksplorasi Kemampuan Kognitif Siswa Terhadap Kemampuan Memprediksi, Mengobservasi, Dan Menjelaskan Ditinjau Dari Gender." Jurnal Pendidikan Fisika Universitas Muhammadiyah Metro 5, no. 2 (2017): 111-18.

Sholihah, Silfi Zainatu, and Ekasatya Aldila Afriansyah. "Analisis Kesulitan Siswa Dalam Proses Pemecahan Masalah Geometri Berdasarkan Tahapan Berpikir Van Hiele." Mosharafa 6, no. 2 (2017): 287-98. https://doi.org/10.31980/mosharafa.v6i2.317.

Susanah. "Pengembangan Lembar Kegiatan Mahasiswa Matematika Dasar." Buana Matematika: Jurnal Ilmiah Matematika Dan Pendidikan

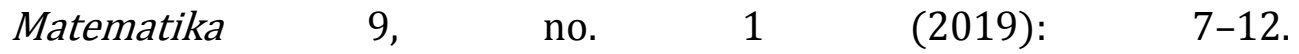
https://doi.org/10.36456/buana_matematika.9.1:.1977.7-12.

Wahyuningsih, Atik Nur, and Kustiarini. "Pengembangan Perangkat Pembelajaran Menggambar Berbasis Outdoor Learning Bagi Siswa Sekolah Dasar." Jurnal Riset Pendidikan Dasar 01, no. 2 (2018): 84-100.

Widadi, Sri, Mega Teguh Budiarto, and Tatag Yuli Eko Siswono. "Pengembangan Perangkat Pembelajaran Dengan Pemecahan Masalah Untuk Melatih Kemampuan Berpikir Kreatif Siswa Kelas IV SD Materi Pecahan." Jurnal Review Pendidikan Dasar 2, no. 2 (2016): 152-58.

Wirda, Mona Adria, Rosni, Nurmala Berutu, and Riki Rahmad. "Pengembangan Lembar Kerja Mahasiswa (LKM) Berbasis Project Pada Mata Kuliah Evaluasi Hasil Belajar Geografi TA 2017/2018." Jurnal Geografi 10, no. 2 (2018): 164-75.

Zamzam, Kenys Fadhilah, Siti Napfiah, and Asri Putri Anugraini. "Persepsi Mahasiswa Terhadap LKM Geometri Transformasi Berbasis Discovery Learning Dengan Pendekatan Kontekstual." Jurnal Matematika Dan Pembelajaran 6, no. 1 (2018): 65-69. 